\title{
Biomass Production, Carbon Stock, and Carbon Sequestration of Dipterocarps at Seedling Stage in Response to Light and Nutrient Availability
}

\author{
Marlito M. Bande ${ }^{1}$, Renezita S. Come ${ }^{2}$, Sheilyn E. Abad ${ }^{1}$, Jimmy \\ O. Pogosa', Hernando L. Mandal, Fidelito M. Almeroda', Elmer \\ M. Napoles ${ }^{1}$
}

${ }^{1}$ Institute of Tropical Ecology and Environmental Management, College of Forestry and Environmental Science, Visayas State University, Baybay City, Leyte Department of Forest Science, College of Forestry and Environmental Science, Visayas State University, Baybay City, Leyte

\begin{abstract}
Presently, there are only a few scientific studies conducted to determine the certified emission reduction (CER) potential of native trees and in promoting the use of dipterocarps in restoring degraded marginal uplands. This study was conducted to determine the biomass production, carbon stock and carbon sequestration potential of dipterocarp seedlings at the hardening stage in the nursery prior to out-planting in response to light and nutrient availability. There were four dipterocarp species used, namely: Shorea contorta, Hopea plagata, Shorea polysperma and Hopea philippinensis. A randomized complete block design between light infiltration and fertilizer application was employed in this study using a total of 144 seedlings. Destructive harvesting was done every month for a period of three months. The results of the study showed that there was a significant $(\mathrm{p} \leq 0.05)$ effect of light infiltration on biomass production and carbon stock of $S$. polysperma and H. philippinensis. However, fertilizer application on biomass production, carbon stock and carbon sequestration of the four dipterocarp species being studied yielded no significant effect.
\end{abstract}

Keywords: carbon stock, carbon sequestration, shade, marginal uplands, rehabilitationorganic carbon

Correspondence : M.M. Bande Address: Institute of Tropical Ecology and Environmental Management, Visayas State University, Visca, Baybay City, Leyte 6521-A Email: mjmbande@yahoo.com DOI: 10.32945/atr36s6.2014 


\section{INTRODUCTION}

Soil and land degradation is a severe global problem of modern times (Lal, 1998) due to various physical and chemical alterations (Steiner, 1996) accelerated by deforestation (Garrrity et al., 1993), overgrazing and unsuitable practices on mountain slopes (Asio et al., 2009). Marginal degraded lands have very low productivity because of soil physical and chemical constraints like acidic or alkaline $\mathrm{pH}$, low organic matter content, low nutrient status, high electrical conductivity, shallow soil, compaction, low rate of water infiltration, low water holding capacity, and unfavorable slopes (Nelson, 1994; Steiner, 1996; Asio, 2007).

The recognition that changes in the land use and forest management activities could be both sources and sinks of carbon led to their inclusion in the Kyoto Protocol (Brown et al., 2002). Article 12 in the Protocol, the Clean Development Mechanism (CDM) allows for emission-offset trading between industrialized and developing countries, while at the same time assisting developing countries achieve sustainable development (Brown et al., 2002). Meanwhile, Article 3.4 provides for additional humaninduced activities such as forest and cropland management, grazing land management and re-vegetation, as carbon sinks or expanding the storage of carbon (Niles et al., 2002). However, Brown et al., (2002) pointed out that the emission reductions resulting from such activities should be real, measurable, long-term benefits related to mitigation of climate change and additional to any that would occur without such activities.

During the past decade, the Philippine government's policies on forest management have shifted from a focus on large-scale, timber-oriented industrial forestry to multiple-product, people-oriented small-scale tree farming (Mangaoang, 2002; Gregorio et al., 2012). Herbohn et al. (2009a) reported that existing tree farms on Leyte Island comprise almost entirely two exotic species, namely: gmelina (Gmelina arborea) and mahogany (Swietenia macrophylla). These species were widely planted during the National Forestation Program (NFP) of the Department of Environment and Natural Resources (DENR) during the 1990s (Harrison et al., 2004). There have been several local and national initiatives to promote planting of native trees where "Rainforestation System" was one of these strategies that started in Leyte Island in 1991. Under this system, fast growing native species were planted first with successional species and then with dipterocarps and fruit trees in the subsequent year. National laws (i.e., DENR Memorandum Circular 2004-06) have been enacted to promote 
planting of native trees. The most recent being the National Greening Program (Executive Order 26) which aims to establish 1.5 billion native trees during the next five years (DENR, 2011). Hence, this study was conducted to promote the use of indigenous forest tree species in restoring and enhancing biodiversity in marginal uplands.

As of the period, there is no scientific study conducted to determine the certified emission reduction's (CER) potential of dipterocarps at seedling stage prior to out-planting. Therefore, this study was conducted in order to quantify the biomass production of dipterocarp seedlings as affected by shade and fertilizer treatments during the hardening stage at the nursery. Likewise, the study will measure the carbon stock and assess the carbon sequestration potential of dipterocarp seedlings in response to shade and fertilizer application prior to field planting.

\section{MATERIALS AND METHODS}

\section{Location and climatic condition of the study site}

The study site was conducted at the Institute of Tropical Ecology and Environmental Management (ITEEM) nursery area, Visayas State University, Baybay City Leyte from March to June, 2013. The average annual precipitation of the study area was $2620 \mathrm{~mm}$ and mean annual temperature of $27.5^{\circ} \mathrm{C}$. According to Balzer and Margraf (1994), temporary droughts has occurred which is attributed to its maximum potential evaporation in May and its minimum in December leading to a short dry period in May. The average total amount of annual potential evaporation is $1205 \mathrm{~mm}$; thus, the net annual precipitation is only 1415 $\mathrm{mm}$.

\section{Experimental design and selection of dipterocarp seedlings}

A randomized complete block design with three replications was employed in this study. Each replication was subdivided into four dipterocarp species. The seedlings selected were, namely: white lauan (Shorea contorta), yakal saplungan (Hopea plagata), tanguile (Shorea polysperma), and guisok-guisok (Hopea philippinensis). An alleyway was provided between main treatments to facilitate nursery operation and management. The shading served as the main treatment (i.e., $100 \%, 70 \%$, $50 \%$ and $30 \%$ light infiltration) and the application of fertilizer was the 
sub-treatment (i.e., with fertilizer, without fertilizer). Six seedlings per replication per sub-treatment per species were used in the experiment. Since there were three replications of four dipterocarp species, a total of 144 seedlings per main treatment were used. Figure 1 shows the experimental design of the study.

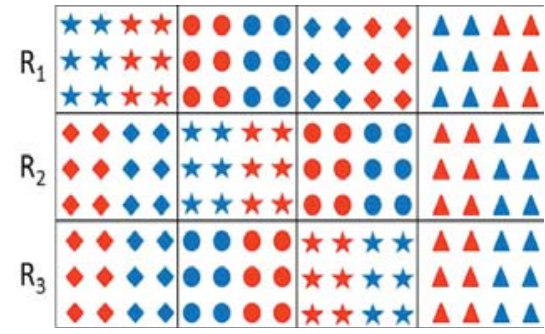

$\mathrm{T}_{0}(100 \%$ light infiltration)

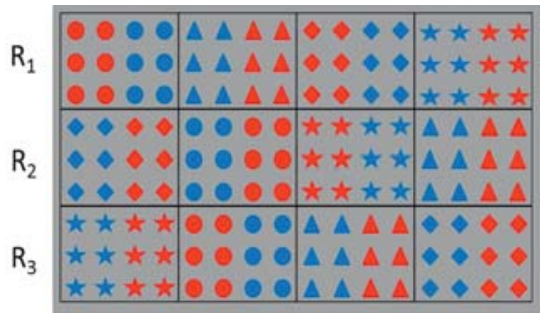

$\mathrm{T}_{3}(50 \%$ light infiltration)

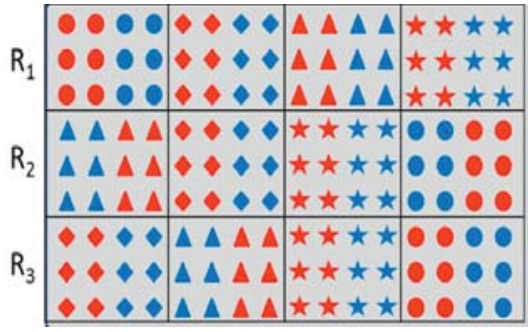

$\mathrm{T}_{1}(70 \%$ light infiltration $)$

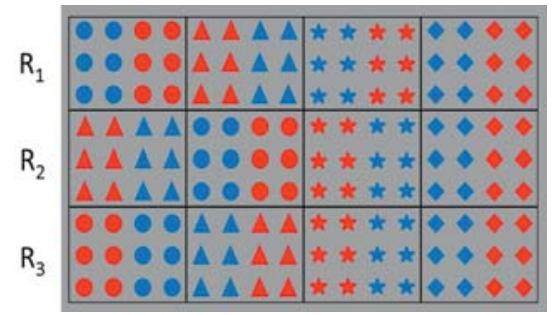

$\mathrm{T}_{4}(30 \%$ light infiltration)

Tanguile (without fertilizer)
Tanguile (with fertilizer)
Guisok-guisok (without fertilizer)
Guisok-guisok (with fertilizer)

Legend:

White lauan (without fertilizer)
Yhite lauan (with fertilizer)
Yakal saplungan (without fertilizer)
Yakal saplungan (with fertilizer

Fig. 1 Experimental design of the study plots

\section{Construction of elevated beds and installation of shade nets}

Four elevated hardening beds were constructed with a dimension of $1.1 \mathrm{~m} \times 3.1 \mathrm{~m}$ meters (Fig. 2). These were installed at a height of one (1) meter. The height of the screen was $15 \mathrm{~cm}$ from the table. The adoption of elevated hardening bed was based on the recommendation of ACIAR Quality Seedling Project. 
Two different shade nets made of polypropylene (Bayview Fishing Supply of General Merchandise, Manila) was used namely: B-double ( $4 \mathrm{~mm}$ x $5 \mathrm{~mm}$ mesh size $)$ and dry nets $(2 \mathrm{~mm}$ x $2 \mathrm{~mm}$ mesh size) that permitted $70 \%$ and $50 \%$ of full sunlight, respectively. Likewise, overlapping of Bdouble and A-double nets $(3.5 \mathrm{~mm} \times 2.5 \mathrm{~mm}$ mesh nets that permitted $60 \%$ of full sunlight) was done to attain the $30 \%$ light infiltration treatments. The nets were installed with a dimension of $2.1 \mathrm{~m} \times 5.1 \mathrm{~m}$ at a height of 2.5 meters. Global radiation was recorded everyday using a light meter (Extech Instrument).

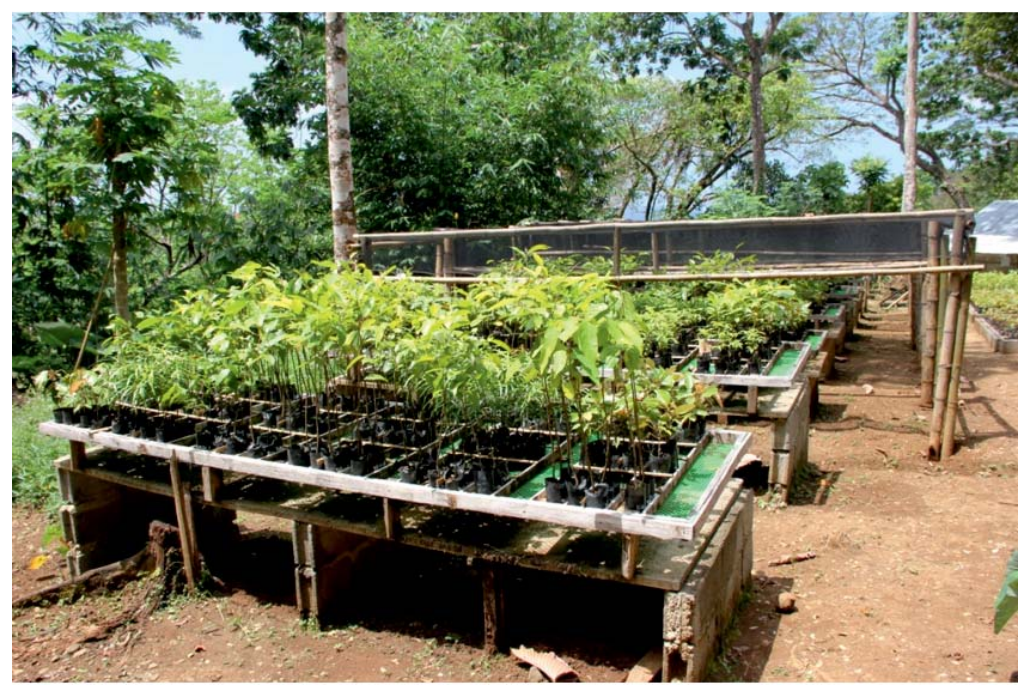

Fig. 2 Construction of elevated bed and installation of shade treatments

\section{Fertilizer application}

Based on the experimental design, fertilizer application served as subtreatments. The $60 \mathrm{~g}$ of $\mathrm{N}$ (Urea) was dissolved to $12 \mathrm{~mL}$ of water and a concentration of $20 \mathrm{cc}$ per seedling was applied to each of the fertilized sub-plots. The application of fertilizer was done every month for a period of three months. 
Destructive harvesting and measurement of biomass, carbon stocks and sequestration

Destructive harvesting was done every month for a period of three months. A total of 48 seedlings were harvested every month. This was conducted to determine the actual biomass production, carbon stock and carbon sequestration of each dipterocarp seedling per species during the hardening period of three months.

The harvested seedlings were partitioned into different plant organs; (i.e., leaves, stem and roots). These partitions were weighed using the top loading balance to determine its fresh weight. After obtaining the fresh weight, the samples were oven dried for 24 hours at $105^{\circ} \mathrm{C}$. These were weighed again to determine its oven dry weight. The total biomass production will be calculated using the formula:

$$
\mathrm{T}_{\mathrm{B}}=\mathrm{L}_{\mathrm{DW}}+\mathrm{S}_{\mathrm{DW}}+\mathrm{R}_{\mathrm{DW}} \quad \text { Equation } 1
$$

where:

$$
\begin{aligned}
& \mathrm{T}_{\mathrm{B}}=\text { Total biomass }(\mathrm{g}) \\
& \mathrm{L}_{\mathrm{DW}}=\text { Leaves dry weight }(\mathrm{g}) \\
& \mathrm{S}_{\mathrm{DW}}=\text { Stem dry weight }(\mathrm{g}) \\
& \mathrm{R}_{\mathrm{DW}}=\text { Roots dry weight }(\mathrm{g})
\end{aligned}
$$

Calculation of carbon was done by multiplying the dry biomass with the default value of carbon $45 \%$ (Lasco and Pulhin, 2000). Likewise, the carbon sequestration was determined by taking the difference between harvests.

\section{Statistical analysis}

All data were tested for normality and homogeneity using PROC Univariate of Statistical Analysis System version 9.1 (SAS, 2003). PROC GLM (general linear model) procedure was initially performed to check for effects of shading and fertilizer application and their interactions on dipterocarp seedling's biomass production, carbon stock and carbon sequestration. The final models for each response variable were analyzed but including only those significant main factors and two-factor interaction effects for each seedling species. Duncan multiple range test (DMRT) and least squares differences (LSD) were carried out to compare treatment means of independent variables with significant variations at $p<0.05$. 


\title{
RESULTS AND DISCUSSION
}

\author{
White lauan (Shorea contorta Vidal)
}

Biomass production in response to light infiltration and fertilizer application treatments

The results showed that the biomass production of the white lauan seedlings at $30 \%$ light infiltration was increased throughout the harvesting period. Popma and Bongers (1988) and Osunkoya et al., (1994) reported that plants at the lower end of the light gradient enhance their light interception, as light becomes a limiting source. Likewise, the study of Rawat et al., (2011) revealed that seedlings of climax species can tolerate shade better as indicated by greater biomass particularly in low light condition.

However, the light infiltration treatments had no significant effect on the biomass production of the seedlings (Fig.3a). According to Gregorio et al., (2009), light affects the synthesis of food within seedling and enhance assimilation of carbon dioxide. It interacts with air temperature in controlling growth rates, and increasing temperature increases the rate of photosynthesis. As irradiance at levels that were beyond the lightresponse curve, plants have mechanism to dispose excess excitation energy safely. Lambers et al., (1998) pointed out that when these mechanisms worked, the quantum yield of photosynthesis was temporarily reduced. This often occurs at high irradiance in many plants.

Moreover, seedlings with no fertilizer tend to have higher amount of biomass produced compared to seedlings with fertilizer (Fig.3b). According to Lambers et al., (1998) factors such as inadequate supply of nutrients greatly increase the proportion of photosynthates used in respiration and this was accounted by much stronger effect of nutrients on biomass allocation when compared with that of irradiance. Statistical analysis showed that fertilizer application had no significant effect on the production of biomass of white lauan seedlings throughout the hardening period. This was probably because the nutrient from the fertilizer was not used by the seedlings due to the effect of elevated hardening on root production. Elevated hardening was designed to reduce lateral root pruning thus root production was prevented. Therefore, root surface area was considerably reduced. Lambers et al., (1998) reported that the rate of nutrient uptake depends on the quantity of root surface area of the plant. 


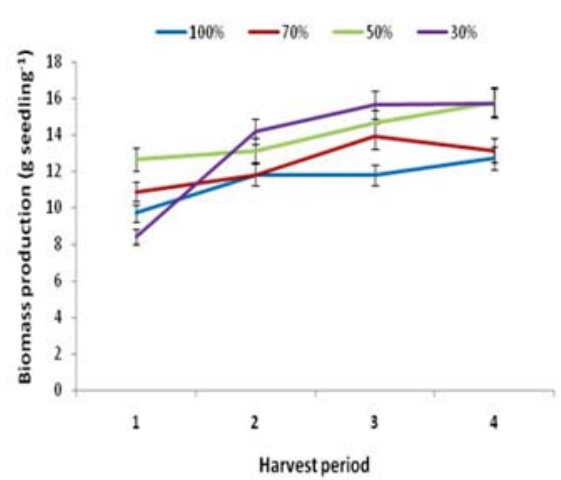

a

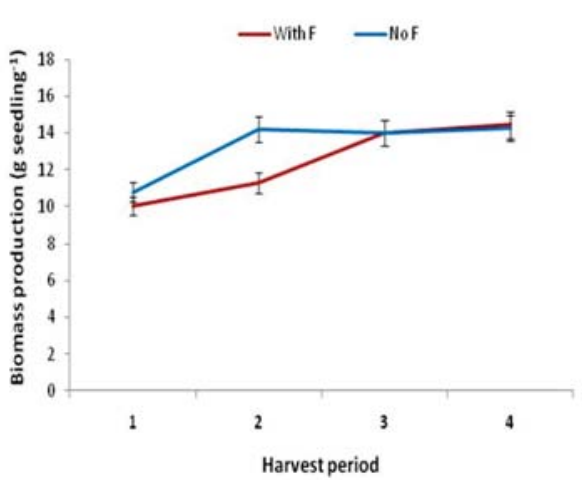

b

Fig 3 Biomass production ( $\mathrm{g}$ seedling ${ }^{-1}$ ) of white lauan as affected by light infiltration (a) and fertilizer treatments (b)

Carbon stock in response to light infiltration and fertilizer application treatments

Figure 4a shows that light infiltration treatments had no significant effect on carbon stock of the seedlings. However, white lauan seedlings under $50 \%$ and $30 \%$ light infiltration consistently stored higher amount of carbon. This was because the seedlings under the two light treatments produced higher biomass. Biomass production and carbon stored are greatly associated to each other wherein it is estimated that approximately half of the biomass of plant is carbon (Lasco and Pulhin, 2000; Johnson and Coburn, 2010).

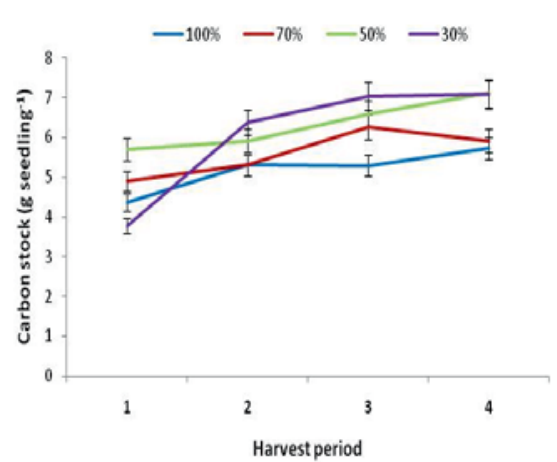

a

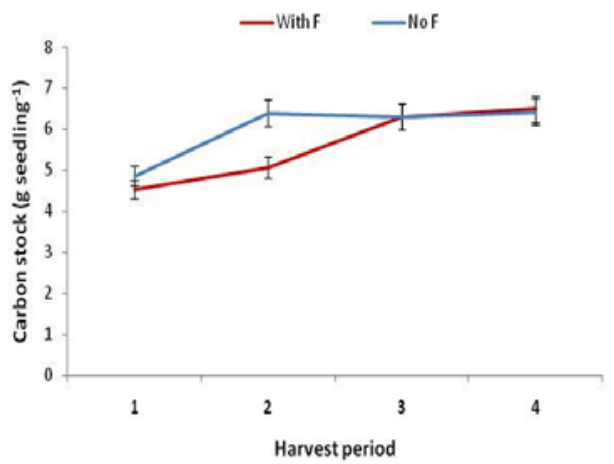

$\mathrm{b}$

Fig 4 Carbon stock (g seedling ${ }^{-1}$ ) of white lauan as influenced by light infiltration (a) and fertilizer treatments (b) 
On the other hand, results showed that fertilizer application had no significant effect on the carbon stock of the seedlings (Fig 4b). This was because nutrient supplied had no significant effect on the white lauan's biomass production. The result was in accordance with the study of Susuki et al., (2010) that the stimulation of $\mathrm{N}$ uptake and assimilation by photosynthesis ensures that $\mathrm{N}$ uptake is correlated with $\mathrm{C}$ status. Hence, application of $\mathrm{N}$ fertilizer to white lauan seedlings during the hardening stage was unnecessary.

Carbon sequestration in response to light infiltration and fertilizer application treatments

According to Lasco and Pulhin (1998), carbon sequestration is the organic assimilation of atmospheric carbon dioxide via photosynthesis. Meanwhile, Johnson and Coburn (2010) suggested that one way in estimating carbon sequestration benefit from reforestation was to determine the difference in average carbon stock between the previous land use and the forest or plantation. In this study, carbon sequestration was determined by calculating the difference among carbon stocks between harvests. Figure 5 presents the carbon sequestration of white lauan as influenced by light infiltration and fertilizer application during the hardening stage at the nursery. The results showed that seedlings under 30\% light infiltration had the highest carbon sequestered (average of $2.60 \mathrm{~g} \mathrm{seedling}^{-1}$ ) compared to seedlings under $100 \%, 70 \%$ and $50 \%$ light infiltration during the first harvest (Fig.5a). During the second and third harvest, carbon sequestration dropped gradually. Finally, at $70 \%$ light infiltration, carbon sequestration was zero during the third period of hardening. This could probably mean that the respiration was equal to the photosynthates or there was no allocation of carbon on the biomass since higher proportion of photosynthates was used in respiration.

Meanwhile, the fertilizer application had no significant effect on the carbon sequestration of seedlings (Fig.5b). According to Poorter et al., (1991), root respiration is accountable to assimilation of carbon each day for approximately $10-50 \%$ in photosynthesis and a major proportion of the plants carbon budget tends to be higher in slow growing plants than in fast growing plants. As root grows through the soil, they intercept some nutrients. This amount, however, is often less than the amount contained in growing roots and therefore cannot serve as a net source of nutrients to the rest of the plants (Lambers et al., 1998). 


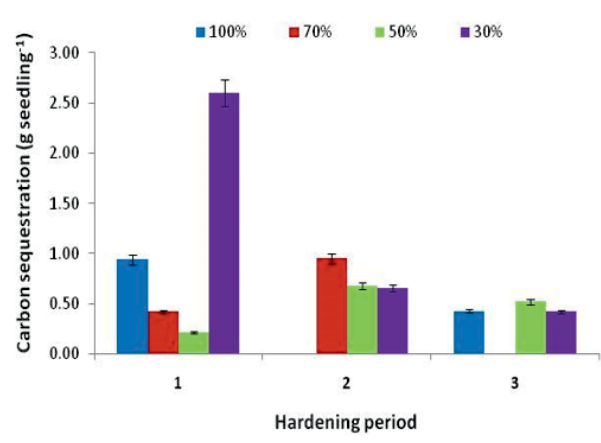

a

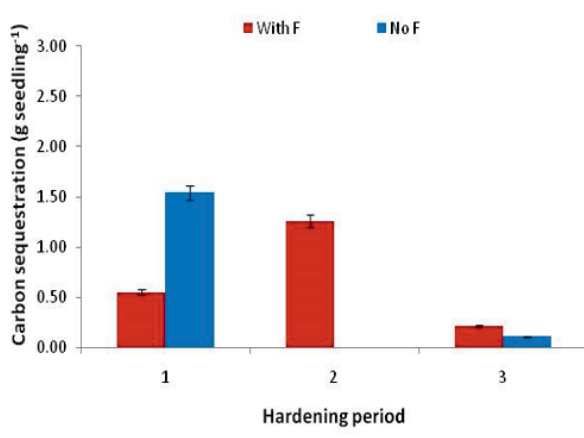

$\mathrm{b}$

Fig 5. Carbon sequestration ( $\mathrm{g}$ seedling ${ }^{-1}$ ) of white lauan as influenced by light infiltration treatments (a) fertilizer treatments (b)

Yakal saplungan [Hopea plagata (Blanco) Vidal]

Biomass production in response to light infiltration and fertilizer application treatments

The results showed that light infiltration treatments had no significant effect on the biomass production of the seedlings. Figure 6a shows that the biomass produced by the seedlings at different light infiltrations considerably decreased when the seedlings were placed at the elevated hardening after one month. This was probably because seedlings were shocked or were not able to cope up with the temperature increase when these were subjected to hardening.

On the other hand, statistical analysis results showed that application of fertilizer had no significant influence on biomass production of yakal saplungan seedlings (Fig.6b). Likewise, seedlings without fertilizer produced higher biomass than seedlings with fertilizer at the final stage of hardening period.

Carbon stock in response to light infiltration and fertilizer application treatments

The seedling at $100 \%$ light infiltration stored lower carbon compared to other seedlings under $30 \%, 50 \%$ and $70 \%$ light infiltration (Fig.7a). The results of statistical analysis showed that light infiltration treatments had no significant effect on carbon stock of yakal saplungan seedlings. 
Meanwhile, fertilizer application had no significant effect on the carbon stock of the seedlings (Fig. 7b). This was because fertilizer had insignificant effect on the biomass production of the seedlings which could be the pronounced effect of elevated hardening on root production of study plant than fertilizer application.

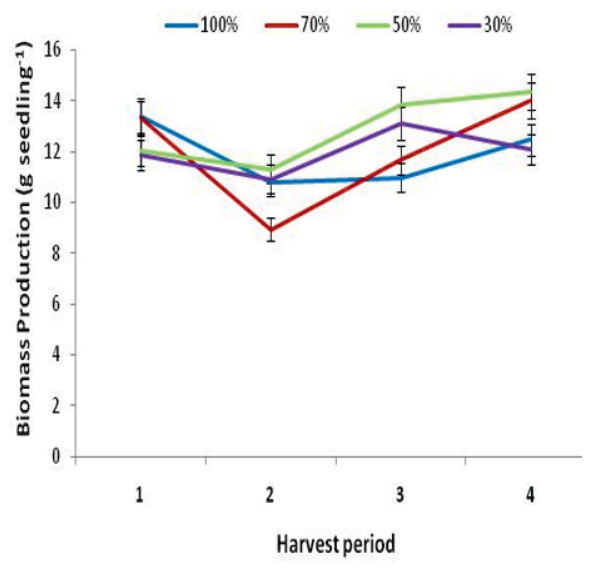

a

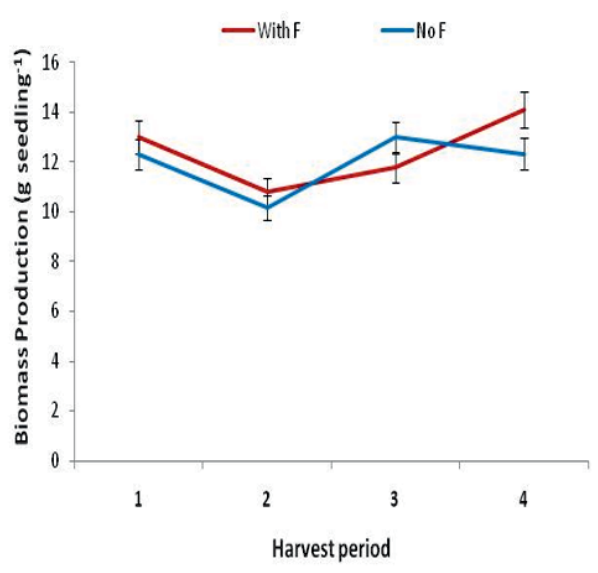

b

Fig 6. Biomass production (g seedling ${ }^{-1}$ ) of yakal saplungan as affected by light infiltration (a) and fertilizer treatments (b)

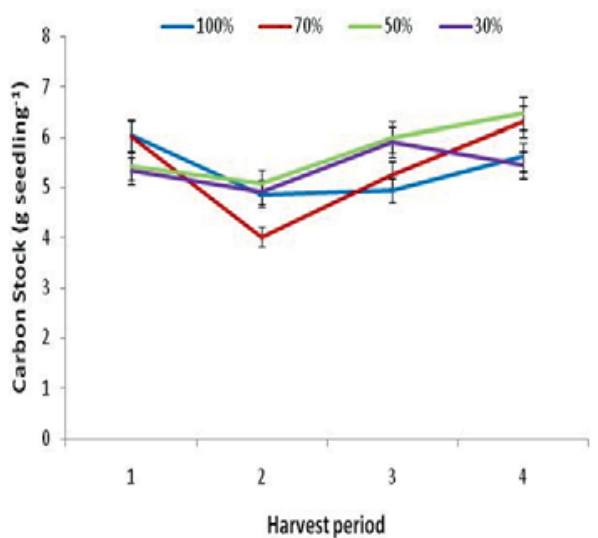

a

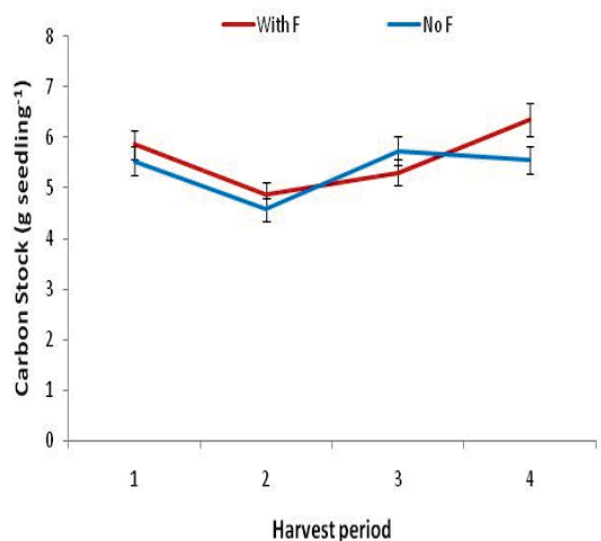

$\mathrm{b}$

Fig 7. Carbon stock ( $\mathrm{g}$ seedling ${ }^{-1}$ ) of yakal saplungan as affected by light infiltration (a) and fertilizer treatments (b) 
Carbon sequestration in response to light infiltration and fertilizer application treatments

The results showed that at first month of hardening yakal saplungan seedlings under different light infiltrations had zero carbon sequestration. This could possibly due to the combined effect of elevated hardening and temperature on the physiology of the seedlings, or it could be that the product during photosynthates was equal to respiration, resulting to zero carbon sequestration. Statistical analysis showed that the light infiltration treatments had no significant effect on the carbon sequestration potential of yakal saplungan seedlings (Fig.8a).

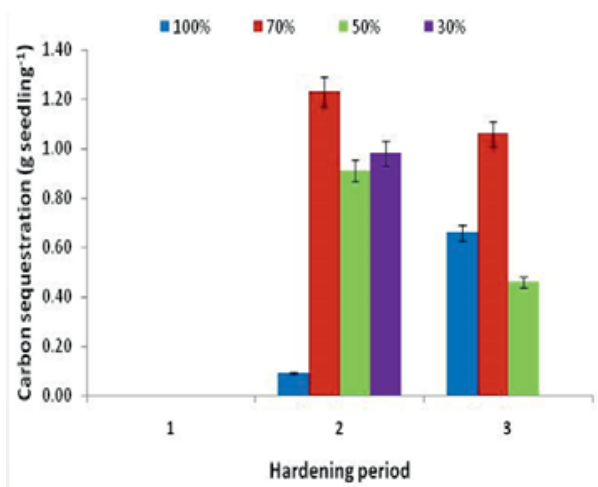

a

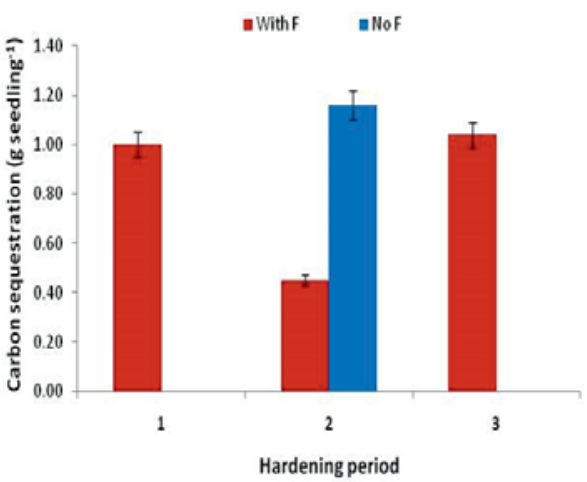

b

Fig 8. Carbon sequestration ( $\mathrm{g}$ seedling ${ }^{-1}$ ) of yakal saplugan as influenced by light infiltration (a) and fertilizer treatments (b)

On the other hand, results showed that seedlings applied with fertilizer had higher sequestration of carbon compared to seedlings with no fertilizer. However, fertilizer application had no significant effect on carbon sequestration potential of the seedlings (Fig. $8 \mathrm{~b}$ ).

Tanguile [Shorea polysperma (Blanco) Merr]

Biomass production in response to light infiltration and fertilizer application treatments

Based on the results, the production of biomass of the seedlings was found to be increasing throughout the harvesting period except on seedlings under $70 \%$ and $100 \%$ light infiltration (Table 1 ). The results of $t$ 
he statistical analysis showed that light infiltration treatments had significant $(\mathrm{p} \leq 0.05)$ effect on the biomass production of tanguile seedlings during the third period of hardening. The significant difference was observed on seedlings under $100 \%$ and $30 \%$ light infiltration treatments. This confirmed that tanguile seedlings are shade-tolerant and are more productive in shaded than grown in open areas.

Table 1. Biomass production ( $\mathrm{g} \mathrm{seedling}^{-1}$ ) of tanguile as affected by light infiltration treatments.

\begin{tabular}{|c|c|c|c|c|}
\hline \multirow{2}{*}{$\begin{array}{l}\text { Light } \\
\text { infiltration } \\
\text { Treatments }\end{array}$} & \multicolumn{4}{|c|}{ Biomass production (g seedling ${ }^{-1}$ ) } \\
\hline & $\underset{\text { (Initial) }}{\text { Harvest } 1}$ & $\begin{array}{c}\text { Harvest } 2 \\
\left(1^{\text {st }} \text { month of hardening }\right)\end{array}$ & $\begin{array}{c}\text { Harvest } 3 \\
\left(2^{\text {nd }} \text { month of hardening }\right)\end{array}$ & $\begin{array}{c}\text { Harvest } 4 \\
\left(3^{\text {rd }} \text { month of hardening }\right.\end{array}$ \\
\hline $100 \%$ & $6.88 \pm 0.75^{\mathrm{ab}}$ & $6.85 \pm 0.95^{\mathrm{a}}$ & $8.55 \pm 1.33^{\mathrm{a}}$ & $8.09 \pm 1.14^{\mathrm{b}}$ \\
\hline $70 \%$ & $6.83 \pm 0.75^{\mathrm{ab}}$ & $9.24 \pm 0.95^{\mathrm{a}}$ & $11.01 \pm 1.33^{\mathrm{a}}$ & $10.45 \pm 1.14^{\mathrm{ab}}$ \\
\hline $50 \%$ & $8.75 \pm 0.75^{\mathrm{a}}$ & $9.46 \pm 0.95^{\mathrm{a}}$ & $9.39 \pm 1.33^{\mathrm{a}}$ & $11.39 \pm 1.14^{\mathrm{ab}}$ \\
\hline $30 \%$ & $6.18 \pm 0.75^{\mathrm{b}}$ & $9.13 \pm 0.95^{\mathrm{a}}$ & $10.93 \pm 1.33^{\mathrm{a}}$ & $13.16 \pm 1.14^{\mathrm{a}}$ \\
\hline
\end{tabular}

Note: Least square means in each column within cell with different letter superscript are significantly different at $\mathrm{p}<0.05, \mathrm{n}=12$

Meanwhile, tanguile seedlings without fertilizer application tended to have higher production of biomass compared to fertilized seedlings (Table 2). This result was similar to that of white lauan seedlings where fertilizer treatments considerably increased its production. However, statistical analysis showed that fertilizer application had no significant effect on biomass production of tanguile seedlings.

Table 2. Biomass production ( $\mathrm{g} \mathrm{seedling}^{-1}$ ) of tanguile as affected by fertilizer application treatments.

\begin{tabular}{lcccc}
\hline \multicolumn{1}{c}{ Fertilizer } & \multicolumn{4}{c}{ Biomass production $\left(\mathrm{g}\right.$ seedling $\left.{ }^{-1}\right)$} \\
\cline { 2 - 5 } & $\begin{array}{c}\text { Harvest 1 } \\
\text { (Initial) }\end{array}$ & $\begin{array}{c}\text { Harvest 2 } \\
\left(1^{\text {st }} \text { month of hardening) }\right.\end{array}$ & $\begin{array}{c}\text { Harvest 3 } \\
\left(2^{\text {nd }} \text { month of hardening) }\right.\end{array}$ & $\begin{array}{c}\text { Harvest 4 } \\
\left(\text { (rd month of }^{\text {hardening }}\right.\end{array}$ \\
\hline With Fertilizer & $7.16 \pm 0.53^{\mathrm{a}}$ & $8.63 \pm 0.67^{\mathrm{a}}$ & $8.92 \pm 0.94^{\mathrm{a}}$ & $10.75 \pm 0.80^{\mathrm{a}}$ \\
Without Fertilizer & $7.17 \pm 0.53^{\mathrm{a}}$ & $8.71 \pm 0.67^{\mathrm{a}}$ & $11.01 \pm 0.94^{\mathrm{a}}$ & $10.79 \pm 0.80^{\mathrm{a}}$ \\
\hline
\end{tabular}

Note: Least square means in each column within cell with different letter superscript are significantly different at $\mathrm{p}<0.05, \mathrm{n}=12$.

Carbon stock in response to light infiltration and fertilizer application treatments

The results of the statistical analysis showed that light infiltration treatment during the third month of hardening had significant $(\mathrm{p} \leq 0.05)$ effect on the carbon stock of tanguile seedlings (Table 3 ). This was because 
biomass and carbon stock were associated to each other. Hence, significant effect was found between low light condition specifically at 30\% light infiltration and open condition or 100\% light infiltration during the third period of hardening. Therefore, tanguile seedlings must be placed at $30 \%$ light infiltration to gain higher amount of biomass and to store more carbon.

Table 3. Carbon stock (g seedling ${ }^{-1}$ ) of tanguile as influenced by light infiltration treatments.

\begin{tabular}{ccccc}
\hline \multirow{2}{*}{$\begin{array}{c}\text { Light } \\
\text { infiltration } \\
\text { Treatments }\end{array}$} & $\begin{array}{c}\text { Harvest 1 } \\
\text { (Initial) }\end{array}$ & $\begin{array}{c}\text { Carbon stock }\left(\mathrm{g} \text { seedling }{ }^{-1}\right) \\
\left(1^{\text {st }} \text { month of hardening }\right)\end{array}$ & $\begin{array}{c}\text { Harvest 3 } \\
(2 \text { nd month of hardening) }\end{array}$ & $\begin{array}{c}\text { Harvest 4 } \\
\left(3^{\text {rd }} \text { month of hardening) }\right.\end{array}$ \\
\cline { 2 - 5 } & $3.10 \pm 0.34^{\mathrm{ab}}$ & $3.09 \pm 0.43^{\mathrm{a}}$ & $3.85 \pm 0.60^{\mathrm{a}}$ & $3.64 \pm 0.51^{\mathrm{b}}$ \\
$70 \%$ & $3.08 \pm 0.34^{\mathrm{ab}}$ & $4.16 \pm 0.43^{\mathrm{a}}$ & $4.95 \pm 0.60^{\mathrm{a}}$ & $4.71 \pm 0.51^{\mathrm{ab}}$ \\
$50 \%$ & $3.94 \pm 0.34^{\mathrm{a}}$ & $4.26 \pm 0.43^{\mathrm{a}}$ & $4.22 \pm 0.60^{\mathrm{a}}$ & $5.13 \pm 0.51^{\mathrm{ab}}$ \\
$30 \%$ & $2.79 \pm 0.34^{\mathrm{b}}$ & $4.11 \pm 0.43^{\mathrm{a}}$ & $4.92 \pm 0.60^{\mathrm{a}}$ & $5.92 \pm 0.51^{\mathrm{a}}$ \\
\hline
\end{tabular}

Note: Least square means in each column within cell with different letter superscript are significantly different at $\mathrm{p}<0.05, \mathrm{n}=12$

With regards to the seedlings without fertilizer application, results showed that these stored more carbon compared to seedlings with fertilizer (Table 4). This observation was similar to white lauan and yakal saplungan. This was because fertilizer application had insignificant effect on the biomass production of the seedlings. This could be due to the effect of temperature and elevated hardening on the physiology of the plant. Likewise, the effect of fertilizer application cannot off-set the effect of light infiltration on the biomass production and carbon storage of tanguile.

Table 4. Carbon stock (g seedling ${ }^{-1}$ ) of tanguile as influenced by fertilizer application treatments.

\begin{tabular}{lcccc}
\hline \multirow{2}{*}{$\begin{array}{c}\text { Fertilizer } \\
\text { Treatment }\end{array}$} & $\begin{array}{c}\text { Harvest 1 } \\
\text { (Benchmark) }\end{array}$ & $\begin{array}{c}\text { Harvest 2 } \\
\left(1^{\text {st }} \text { month of hardening }\right)\end{array}$ & $\begin{array}{c}\text { Harvest 3 } \\
\left(2^{\text {nd }} \text { month of hardening }\right)\end{array}$ & $\begin{array}{c}\text { Harvest 4 } \\
\left(3^{\text {rd }} \text { month of hardening }\right)\end{array}$ \\
\cline { 2 - 5 } With Fertilizer & $3.22 \pm 0.24^{\mathrm{a}}$ & $3.87 \pm 0.30^{\mathrm{a}}$ & $4.02 \pm 0.42^{\mathrm{a}}$ & $4.84 \pm 0.36^{\mathrm{a}}$ \\
Without Fertilizer & $3.23 \pm 0.24^{\mathrm{a}}$ & $3.92 \pm 0.30^{\mathrm{a}}$ & $4.95 \pm 0.42^{\mathrm{a}}$ & $4.86 \pm 0.36^{\mathrm{a}}$ \\
\hline
\end{tabular}

Note: Least square means in each column within cell with different letter superscript are significantly different at $\mathrm{p}<0.05, \mathrm{n}=12$

Carbon sequestration in response to light infiltration and fertilizer application treatments

According to Johnson and Coburn (2010), trees remove carbon dioxide from the atmosphere through the natural process of photosynthesis and store the carbon in their leaves, branches, stem, bark and roots. The result 
of this study showed that light infiltration treatment had no significant effect on carbon sequestration of tanguile seedlings (Fig.9a). Likewise, seedlings under $100 \%$ and $70 \%$ light infiltration had zero carbon sequestration during the third month of hardening. Sasaki (2010) reported that plants in high light are faced with high load of radiation, which could affect the biomass production, as well as carbon sequestration of the plants.

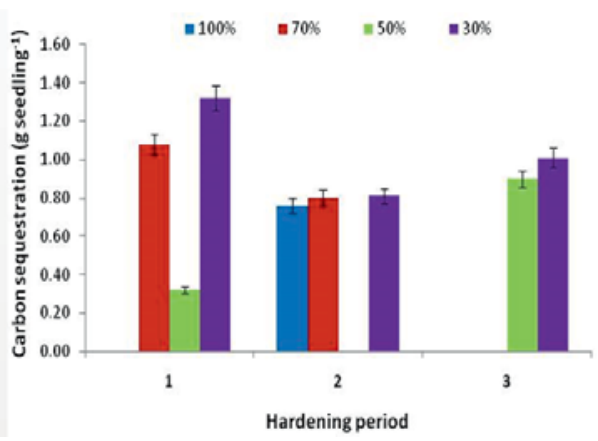

a

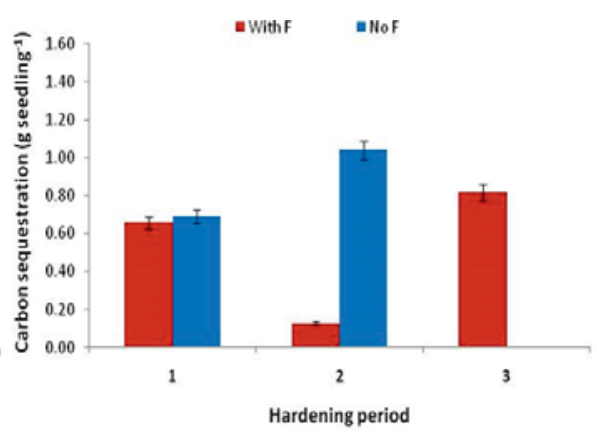

b

Fig 9. Carbon sequestration ( $\mathrm{g}$ seedling ${ }^{-1}$ ) of tanguile as influenced by light infiltration (a) and fertilizer treatments (b)

On the other hand, fertilizer treatment had no significant effect on carbon sequestration of the seedlings (Fig.9b). The zero carbon sequestration found during the third month of hardening on seedlings without fertilizer might be on the physiological effect of light on the biomass production of tanguile seedlings over a period of hardening. Hence, fertilizer application cannot prevent or minimize the effect of light on the biomass production of the seedlings which will result to zero carbon sequestration during the period of hardening.

\section{Guisok-guisok(Hopea philippinensis Dyer)}

Biomass production in response to light infiltration and fertilizer application treatments

The results showed that guisok-guisok seedlings had consistently increased their biomass throughout the hardening period (Table 5) except for seedlings under $100 \%$ light infiltration. Analysis of variance showed that light infiltration treatment had significant $(\mathrm{p} \leq 0.05)$ effect on the biomass production of guisok-guisok during the first month of hardening. 
Table 5. Biomass production ( $\mathrm{g}$ seedling ${ }^{-1}$ ) of guisok-guisok as affected by light infiltration treatments.

\begin{tabular}{|c|c|c|c|c|}
\hline \multirow{2}{*}{$\begin{array}{c}\text { Light } \\
\text { Infiltration } \\
\text { Treatments }\end{array}$} & \multicolumn{4}{|c|}{ Biomass production $\left(\right.$ g seedling $^{-1}$ ) } \\
\hline & $\begin{array}{c}\text { Harvest } 1 \\
\text { (Benchmark) }\end{array}$ & $\begin{array}{c}\text { Harvest } 2 \\
\left(1^{\text {st }} \text { month of hardening }\right)\end{array}$ & $\begin{array}{c}\text { Harvest } 3 \\
\left(2^{\text {nd }} \text { month of hardening }\right)\end{array}$ & $\begin{array}{c}\text { Harvest } 4 \\
\left(3^{\text {rd }} \text { month of hardening }\right)\end{array}$ \\
\hline $100 \%$ & $5.90 .81^{\mathrm{a}}$ & $8.80 \pm 0.14^{\mathrm{a}}$ & $8.39 \pm 0.17^{\mathrm{ab}}$ & $9.05 \pm 1.58^{\mathrm{a}}$ \\
\hline $70 \%$ & $5.63 \pm 0.81^{\mathrm{a}}$ & $7.46 \pm 0.14^{\mathrm{ab}}$ & $8.43 \pm 0.17^{\mathrm{ab}}$ & $11.75 \pm 1.58^{\mathrm{a}}$ \\
\hline $50 \%$ & $4.82 \pm 0.81^{\mathrm{a}}$ & $5.20 \pm 0.14^{\mathrm{b}}$ & $6.15 \pm 0.17^{b}$ & $10.81 \pm 1.58^{\mathrm{a}}$ \\
\hline $30 \%$ & $6.42 \pm 0.81^{\mathrm{a}}$ & $9.08 \pm 0.14^{\mathrm{a}}$ & $10.60 \pm 0.17^{\mathrm{a}}$ & $12.23 \pm 1.58^{\mathrm{a}}$ \\
\hline
\end{tabular}

Note: Least square means in each column within cell with different letter superscript are significantly different at $\mathrm{p}<0.05, \mathrm{n}=12$.

Similar results were found in tanguile seedlings where there was a significant $(p \leq 0.05)$ effect on biomass production under $30 \%$ and $100 \%$ light infiltrations. According to Poorter and Oberbauer (1993), the biomass production is increased by means of a higher light-saturated photosynthetic rate. Thus, even though light infiltration (between 100\% and $30 \%$ light infiltration) had significant ( $\mathrm{p} \leq 0.05)$ effect on biomass production of both guisok-guisok and tanguile seedlings, this was visible at different periods of harvest. As noted, guisok-guisok seedlings were very sensitive to radiation at the early stage of hardening. However, the seedlings were able to recover at the last stage of hardening. In contrary, the response of tanguile seedlings was opposite. The effect of radiation was evident at the final stage of hardening.

According to Susuki et al.. (2010), N uptake by the roots and further N assimilation are integrated in the plant to match the nutrient demand of the seedlings. Results showed that fertilizer application had no significant effect to the biomass production of the guisok-guisok seedlings (Table 6). The effect of fertilizer application on guisok-guisok seedlings was similar to yakal saplungan seedlings. The seedlings with fertilizer application had no considerable difference compared to that of the seedlings without fertilizer. Once again, this confirmed that the effect of light on biomass production of the seedlings was not prevented by the application of fertilizer.

Table 6. Biomass production ( $\mathrm{g} \mathrm{seedling}^{-1}$ ) of guisok-guisok as influenced by fertilizer application treatments.

\begin{tabular}{lcccc}
\hline Fertilizer & \multicolumn{4}{c}{ Biomass production $\left(\mathrm{g}\right.$ seedling $\left.{ }^{-1}\right)$} \\
\cline { 2 - 4 } Treatment & $\begin{array}{c}\text { Harvest 1 } \\
\text { (Benchmark) }\end{array}$ & $\begin{array}{c}\text { Harvest 2 } \\
\left(1^{\text {st }} \text { month of hardening) }\right.\end{array}$ & $\begin{array}{c}\text { Harvest 3 } \\
\left(2^{\text {nd }} \text { month of hardening) }\right.\end{array}$ & $\begin{array}{c}\text { Harvest 4 } \\
(3 \mathrm{r} \text { month of hardening) }\end{array}$ \\
\hline With Fertilizer & $6.02 \pm 0.57^{\mathrm{a}}$ & $7.96 \pm 0.72^{\mathrm{a}}$ & $8.31 \pm 0.75^{\mathrm{a}}$ & $11.57 \pm 1.11^{\mathrm{a}}$ \\
Without Fertilizer & $5.34 \pm 0.57^{\mathrm{a}}$ & $7.31 \pm 0.72^{\mathrm{a}}$ & $8.47 \pm 0.75^{\mathrm{a}}$ & $10.34 \pm 1.11^{\mathrm{a}}$ \\
\hline
\end{tabular}

Note: Least square means in each column within cell with different letter superscript are significantly different at $\mathrm{p}<0.05, \mathrm{n}=12$ 
Carbon stock in response to light infiltration and fertilizer application treatments

Based on the results, seedlings under $30 \%, 50 \%$ and $70 \%$ light infiltration had consistently increased carbon stock of guisok-guisok seedlings throughout the harvesting period. Meanwhile, the seedlings under 100\% light infiltration slightly increased its carbon stock at the third period of hardening (Table 7). However, a significant ( $p \leq 0.05$ ) effect of light infiltration treatments on carbon stock was noted during the first month of hardening. This was mainly because of its significant ( $p \leq 0.05)$ effect on biomass production.

Table 7. Carbon stock (g seedling ${ }^{-1}$ ) of guisok-guisok as influenced light infiltration treatments.

\begin{tabular}{ccccc}
\hline $\begin{array}{c}\text { Light } \\
\text { Infiltration } \\
\text { Treatment }\end{array}$ & $\begin{array}{c}\text { Harvest 1 } \\
\text { (Benchmark) }\end{array}$ & $\begin{array}{c}\text { Carbon stock }(\mathrm{g} \text { seedling } \\
\left(^{-1}\right)\end{array}$ \\
\hline $100 \%$ & $2.66 \pm 0.36^{\mathrm{a}}$ month of hardening) & $\begin{array}{c}\text { Harvest 3 } \\
\left(2^{\text {nd }} \text { month of hardening }\right)\end{array}$ & $\begin{array}{c}\text { Harvest 4 } \\
\left(3^{\text {rd }} \text { month of hardening }\right)\end{array}$ \\
$70 \%$ & $3.96 \pm 0.46^{\mathrm{a}}$ & $3.77 \pm 0.48^{\mathrm{ab}}$ & $4.07 \pm 0.71^{\mathrm{a}}$ \\
$50 \%$ & $2.54 \pm 0.36^{\mathrm{a}}$ & $3.36 \pm 0.46^{\mathrm{ab}}$ & $3.79 \pm 0.48^{\mathrm{ab}}$ & $5.29 \pm 0.71^{\mathrm{a}}$ \\
$30 \%$ & $2.17 \pm 0.36^{\mathrm{a}}$ & $2.34 \pm 0.46^{\mathrm{b}}$ & $2.77 \pm 0.48^{\mathrm{b}}$ & $4.87 \pm 0.71^{\mathrm{a}}$ \\
\hline
\end{tabular}

Note: Least square means in each column within cell with different letter superscript are significantly different at $\mathrm{p}<0.05, \mathrm{n}=12$

Table 8 presents no considerable difference between seedlings with fertilizer and without fertilizer application treatments. The same result was observed on the three other species of dipterocarp seedlings.

Table 8. Carbon stock (g seedling ${ }^{-1}$ ) of guisok-guisok as influenced by fertilizer application treatment.

\begin{tabular}{lcccc}
\hline \multirow{2}{*}{$\begin{array}{c}\text { Fertilizer } \\
\text { Treatment }\end{array}$} & $\begin{array}{c}\text { Carvest 1 } \\
\text { (Benchmark) }\end{array}$ & $\begin{array}{c}\text { Harvest 2 } \\
\left(1^{\text {st }} \text { month of hardening) }\right.\end{array}$ & $\begin{array}{c}\text { Harvest 3 } \\
\left(2^{\text {nd }} \text { month of hardening }\right)\end{array}$ & $\begin{array}{c}\text { Harvest 4 } \\
\left(3^{\text {rd }} \text { month of hardening }\right)\end{array}$ \\
\cline { 2 - 5 } With Fertilizer & $2.71 \pm 0.26^{\mathrm{a}}$ & $3.58 \pm 0.32^{\mathrm{a}}$ & $3.74 \pm 0.34^{\mathrm{a}}$ & $5.21 \pm 0.50^{\mathrm{a}}$ \\
Without Fertilizer & $2.42 \pm 0.26^{\mathrm{a}}$ & $3.29 \pm 0.32^{\mathrm{a}}$ & $3.81 \pm 0.34^{\mathrm{a}}$ & $4.65 \pm 0.50^{\mathrm{a}}$ \\
\hline
\end{tabular}

Note: Least square means in each column within cell with different letter superscript are significantly different at $\mathrm{p}<0.05, \mathrm{n}=12$

Carbon sequestration in response to light infiltration and fertilizer application treatments

Figure 10a shows that at $50 \%$ light infiltration, carbon sequestration of guisok-guisok seedlings was high (average of 2.10 g seedling $^{-1}$ ) during the 
third period of hardening. This was because biomass production and carbon stock at this period were high. However, at $100 \%$ light infiltration the seedling had a zero carbon sequestration during the second month of hardening. This could probably be due to the result that at this stage, the amount of photosynthates was equal to the respiration of the seedlings. Thus, no carbon sequestration was recorded. Finally, the results of statistical analysis showed that light infiltration treatment had no significant effect on carbon sequestration potential of the seedlings.

Based on the results of the statistical analysis, fertilizer application had no significant effect on carbon sequestration of the seedlings (Fig.10b). This was because fertilizer application had insignificant effect on the biomass and carbon stock of the seedlings.

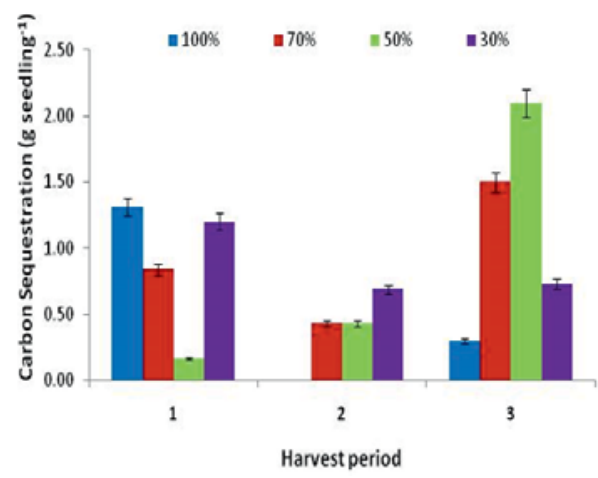

a

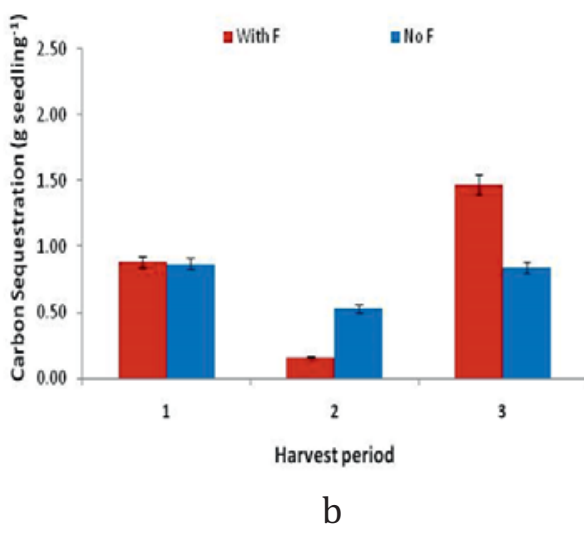

$\mathrm{b}$

Fig 10. Carbon sequestration ( g seedling $^{-1}$ ) of guisok-guisok as influenced by light infiltration (a) and fertilizer treatments (b).

\section{CONCLUSIONS}

This study was conducted to quantify the biomass production, measure the carbon stock and assess the carbon sequestration of dipterocarp seedlings in response to shade and fertilizer treatments at the nursery. Based on the results of this study, the following conclusions are generated:

a) Light infiltration significantly $(\mathrm{p} \leq 0.05)$ enhanced the biomass production and carbon stock of S. polysperma and H. philippinensis;

b) Fertilizer application had no significant effect on biomass production, carbon stock and carbon sequestration of the four 
dipterocarp species studied at the nursery; and

c) Among the four dipterocarps that where studied in the nursery white lauan stored the highest amount of carbon, $(7.11 \pm 0.56 \mathrm{~g}$ seedling ${ }^{-1}$ ) followed by tanguile (5.92 $\pm 0.51 \mathrm{~g}$ seedling $\left.{ }^{-1}\right)$, yakal saplungan (5.61 $\pm 0.86 \mathrm{~g}$ seedling $\left.{ }^{-1}\right)$ and guisok-guisok (5.50 \pm 0.71 g seedling $^{-1)}$.

\section{ACKNOWLEDGEMENT}

This study was funded by the Commission on Higher Education under the PHERNet Program of the Visayas State University.

\section{REFERENCES}

AERTS R (1996) Nutrient resorption from senescing leaves of perennials: Are there general patterns? Journal of Ecology 84:597-608

AKHTER N, M.M. RAHMAN, M HASANUZZAMAN, and K. NAHAR (2009) Physiological response of garden pea (Pisum sativum L.) grown under different light environment. Botany Research International 2(4):304309

ALLEN C.B., R.E. WILL , R.C. MCGARVEY , D.R. COYLE, and M.D. COLEMAN (2004) Radiation-use efficiency and gas exchange responses to water and nutrient availability in irrigated and fertilized stands of sweetgum and sycamore. Tree Physiology 25:191-200

ASIO V.B. 2007. Characteristics, fertility status and management of degraded upland soils in Leyte. PARRFI Professional Chair Papers: 1992-2006. Philippine Agriculture Resource Research Foundation In. (PARRFI), Los Baños, Laguna.

ASIO V.B., R. JAHN, F.O. PEREZ, I.A. NAVARRETE and S.M. ABIT, Jr. 2009. A Review of soil degradation in the Philippines. Annals of Tropical Research 31:69-94.

BALSTER N.J. and J.D. MARSHALL. (2000) Eight-year responses of light interception, effective leaf area index, and stemwood production in fertilized stands of interior Douglas-fir (Pseudotsuga menziesii var. glauca).Can.J. For. Res. 30:733-743 
Biomass Production, Carbon Stock, and Carbon Sequestration of Dipterocarps

BALZER, P. and J. MARGRAF. 1994. Recent rainfall trends in ViSCA, Baybay, Leyte, Philippines. Annals of Tropical Research 16 (4), 32-42

BJÖRKMAN O., and P. HOLMGREN. (1966) Photosynthetic adaptation to light intensity in plants native to shaded and exposed habitats. Physiol. Plant. 19:854-889

BJÖRKMAN O. (1981) Responses to different quantum flux densities. In: Lange OL, Nobel PS, Osmond CB, Ziegler H (eds) Encyclopaedia of Plant Physiology, New Series, vol. XII A, Springer-Verlag, Berlin, pp37-107

BOARDMAN N.K. (1977) Comparative photosynthesis of sun and shade plants. Ann. Rev. Plant Physiol. 28:355-377

BROWN, S., SWINGLAND, I.R., HANBURY-TENISON, R., PRANCE, G.T. and MYERS, N. 2002. Changes in the use and management of forests for abating carbon emissions: issues and challenges under the Kyoto Protocol. Phil. Trans. R. Soc. Lond. A 360: 1593-1605

BUISSON D., and D.W.LEE (1993) The developmental responses of papaya leaves to simulated canopy shade. Am.J. Bot. 80:947-952

CALISKAN O., M.S. ODABAS, and C. CIRAK (2009) The modelling of the relation among the temperature and light intensity of growth in Ocimum basilicum L. Journal of Medicinal Plants Research 3(11):965977

CANNELL M.G.R. (1985) Physiology of coffee crop. In: Clifford MN, Wilson KC (eds) Coffee botany, biochemistry and production of beans and beverages, London, Croom Helm, pp108-124.

Department of Environment and Natural Resources (DENR). 2011. Executive Order No. 26,National Greening Program, accessed 10 August 2012 http://ngp.denr.gov.ph/.

DURIYAPRAPAN S., and E.J. BRITTEN(1982) The effects of solar radiation on plant growth, oil yield and oil quality of Japanese mint. Journal of Experimental Botany 33(137):1319-1324 
EVANS J.R. (1983) Nitrogen and photosynthesis in the flag leaf of wheat (Triticum eastivum L.). Plant Physiol. 72:297-302

FIELD C., and H.A. MOONEY (1986) The photosynthesis-nitrogen relationships in wild plants. In: Givinish TJ (ed) On the economy of form and function. Cambridge University Press, Cambridge, England, pp2555

GARRITY, D.P., D.M. KUMAR and E.S. GUIANG. 1993. The Philippines. In: Committee on Sustainable Agriculture and Environment in the Humid Tropics. BOSTID. NRC. Washington. D.C.

GERIK T.J., D.M. OOSTERHUIS and H.A. TORBERT (1998) Managing cotton nitrogen supply. Adv. Agron. 64:115-147

GOLTSEV V., I.ZAHARIEVA, P. LAMBREV, I. YORDANOV, and R. STRASSER (2003) Simultaneous analysis of prompt and delayed chlorophyll a fluorescence in leaves during the induction period of dark to light adaptation. J. Theoretical Biol. 225:171-183

GREGORIO, N.O., VANCLAY, J. and HERBOHN, J.L. 2009. Establishing field trials to promote smallholder forestry in Leyte, The Philippines. In S.R. Harrison, A. Bosch, J. Herbohn and E. Mangaoang (eds) Proceedings from the End-of-Project Workshop held in Ormoc City,the Philippines. ACIAR Smallholder Forestry Project: Improving Financial Returns to Smallholder Tree Farmers in the Philippines, End-of-Project Workshop, Sabin Resort Hotel, Ormoc City, Leyte, (75-82). 11-12 February 2009.

GREGORIO, N.O., HERBOHN, J.L., and VANCLAY, J. K. 2012. Developing establishment guidelines for Shorea palosapis in smallholder plantings in the Philippines. International Forestry Review Vol.14(4), 2012

HARRISON, S., EMTAGE, N.F. and NASAYAO, E.E. 2004. Past and present forestry support programs in the Philippines, and lessons for the future.Small-Scale Forestry 3: 303-317. 
HERBOHN, J., GREGORIO, N. and VANCLAY, J. 2009a. Rationale and key research questions addressed by field trails established as part of the ACIAR Smallholder Tree Farmer Project. In: S. Harrison, A. Bosch, J. Herbohn and E. Mangaoang (eds) ASEM/2003/052 Improving Financial Returns to Smallholder Tree Farmers in the Philippines End-of-Project Workshop held in Ormoc City, the Philippines, 11-12 February 2009. pp. 67-74.

HOLMGREN P. (1968) Leaf factors affecting light-saturated photosynthesis in ecotypes of Solidago_virgaurea_from exposed and shaded habitats. Physiol. Plant. 21:676-698

ISAAC M.E., V.R. TIMMER, and S.J. QUASHIE-SAM. (2007) Shade tree effects in an 8-year-old cocoa agroforestry system: biomass and nutrient diagnosis of Theobroma cacao by vector analysis. Nutrient Cycling in Agroecosystems, Springer Science-Business Media, B.V. doi:10705-006-9081-3

JOHNSON, I. and R. COBURN, F. 2010. Trees for carbon sequestration, Climate in Primary Industries, Forest Science Centre, West Pennant Hills (accessed Jan.6, 2014)

KAMALUDDIN M., and J. GRACE. (1992) Photoinhibition and light acclimation in seedlings of Bischofia javanica, a tropical forest tree from Asia. Annals of Botany 69:47-52

KEMANIAN A.R., C.O .STÖCKLE, and D.R. HUGGINS (2004) Variability of barley radiation-use efficiency. Crop Sci. 44:1662-1672

LAL, R. 1998. Soil Quality and Sustainability, In: Methods in Assessment of Soil Degradation. Advances in Soil Science. CRC Pren, BOCA Ration. pp.17-30.

LASCO, R.D. and B.F. PULHIN. 1998. Philippine Forestry and Carbon Dioxide $\left(\mathrm{CO}_{2}\right) \quad$ Sequestration Opportunities for Mitigating Climate Change

LASCO, R.D. and B.F. PULHIN. 2003. Philippine forest ecosystems and climate change: Carbon stocks, rate of sequestration and the Kyoto Protocol. 
LAMBERS H., F.S. CHAPIN, and T.L. PONS (1998) Plant Physiological Ecology. Springer-Verlag New York, USA

MANGAOANG, E.O. 2002. A forester's perspective of the socio-economic information requirements for forestry in Leyte. In: S. Harrison, J. Herbohn, E. Mangaoang and J. Vanclay (eds), Socio-economic Research Methods in Forestry: A Training Manual, Cooperative Research Centre for Tropical Rainforest Ecology and Management, Rainforest CRC, Cairns, pp. 1-14.

NELSON, R.A. 1994. Soil erosion and conservation in the Philippine uplands. A review of literature. SEARCA - UQ Uplands Research Project

NILES, J.O., BROWN, S., PRETTY, J., BALL, A.S. and FAY, J. 2002. Potential carbon mitigation and income in developing countries from changes in use and management of agricultural and forest lands. Phil. Trans. R. Soc. Lond. A 360: 1621-1639

OSMOND, C.B., 1994. What is photoinhibition? Some insights from comparison of shade and sun plants, in: Baker, N.R., Bowyer, J.R. (Eds.), Photoinhibition of photosynthesis-from molecular mechanisms to the field, BIOS Scientific Publishers, Lancaster, pp. 1-24.

OSUNKOYA, O.O., ASH, J.E., HOPKINS, M.S., and GRAHAM, A.W. 1994. Influence of seed size and seedling ecological attributes on shade-tolerance of rainforest tree species in Northern Queensland. Journal of Ecology 13, 149-163.

POORTER, L., VAN DER WERF, A., ATKIN, O.K., and LAMBERS, H. 1991. Respiratory energy requirements of roots vary with the potential growth rate of a plant species. Physio.Plant. 83:469-475

POORTER, L. and OBERBAUER, S.F. 1993. Photosynthetic induction responses of two rainforest tree species in relation to light environment. Oecologia 13, 193-199.

POPMA, J., and BONGERS, F. 1988. The effect of canopy gaps on growth and morphology of seedlings of rainforest species. Oecologia 13, 625-632

POWLES, S.B., 1984. Photoinhibition of photosynthesis induced by visible light. Annual Review of Plant Physiology 35, 15-44. 
RAVEH, E., S. COHEN, T. RAZ, , D. YAKIR, A. GRAVA, and E.E. GOLDSCHMIDT. 2003. Increased growth of young citrus trees under reduced radiation load in a semi-arid climate. Journal of Experimental Botany 54(381), 365-373.

RAWAT, Y.S., BARGALI, S.S., and BARGALI, K. 2011. Carbon stock and shade tolerance in seedlings of some early and late successional tree species of Central Himalaya (accessed April 8, 2014)

SAIFUDDIN, M., A.M.B. HOSSAIN, and O. NORMANIZA. 2010. Impacts of shading on flower formation and longevity, leaf chlorophyll and growth of Bougainvillea glabra.Asian Journal of Plant Sciences 9(1), 20-27.

SAS, 2003. The SAS systems for Windows. SAS Institute, Inc. Cary, North Carolina, USA.

SASAKI, S. 2010. Physiological characteristics of tropical rainforest tree species. A basis for the development of silvicultural technology. Ann Bot. 105(7): 1141-1157 (accessed April 8, 2014)

SÖNDAHL, M.R., H.A.M. VAN DER VOSSEN, A.M. PICCIN, and F. ANZUETO 2005. The plant, in: Viani, R. (Ed.), Expresso coffee: the chemistry of quality, second ed. Academic Press Ltd, London

STANHILL, G., and S. COHEN. 2001. Global dimming: a review of the evidence for a widespread and significant reduction in global radiation with discussion of its probable causes and possible agricultural consequences. Agricultural and Forest Meteorology 107, 255-278.

STEINER, K.G. 1996. Causes of soil degradation and development upwards to sustainable soil management. Margraf Verlag, Weikersheim,

STOVER, R.H., 1984. Canopy management in Valery and Grand Nain using leaf area index and photosynthetically active radiation measurements. Fruits 39, 89-93.

SUSUKI, A., GAUFICHON, L., CHARDON, F., DECHORGNAT, J., DANIELVEDELE, F., and MAXCLAUX-DAUBRESSE, C. 2010. Nitrogen uptake, assimilation and remobilization in plants: challenges for sustainable and productive agriculture. Ann Bot.105 (7):1141-1157. (Accessed April 8 2014) 
SYVERTSEN, J.P., and M.L. SMITH. 1984. Light acclimation in citrus leaves. I. Changes in physical characteristics, chlorophyll and nitrogen content. Journal of the American Society for Horticultural Science 109, 807-812.

TORQUEBIAU, E., and E. AKEAMPONG. 1994. Shedding some light on shade.Agroforestry Today, Oct-Dec 1994: 14-15.

VALLADARES, F., and Ü. NIINEMETS. 2008. Shade tolerance, a key plant features of complex nature and consequences. Annu. Rev. Ecol. Evol. Syst. 39, 237-257.

VAN DER VOSSEN H.A.M. 1985. Coffee selection and breeding, in: Clifford, M.N., Wilson, K.C. (Eds.), Coffee botany, biochemistry and production of beans and beverages, London, Croom Helm, pp. 48-96.

VAN DER VOSSEN, H.A.M. 2005. A critical analysis of the agronomic and economic sustainability of organic coffee production. Expl. Agric. 41, 449-473.

WILL, R.E., BARON G.A., BURKES, E.C., SHIVER, B., TESKEY, R.O., 2001. Relationship between intercepted radiation, net photosynthesis, respiration and rate of stem volume growth of Pinus taeda and Pinus elliottii stands of different densities. For. Ecol. Manage. 154, 155-163.

YANG, J., and J. ZHANG. 2006. Tansley review, grain filling of cereals under soil drying. New Phytol. 169, 223-236.

ZHAO, D., K.R. REDDY, V.G. KAKANI, J.J. READ, and G.A. CARTER, 2003. Corn (Zea mays L.) growth leaf pigment concentration, photosynthesis and leaf hyperspectral reflectance properties as affected by nitrogen supply. Plant Soil 257, 205-217. 